\title{
Blastobotrys americana sp. nov., Blastobotrys illinoisensis sp. nov., Blastobotrys malaysiensis sp. nov., Blastobotrys muscicola sp. nov., Blastobotrys peoriensis sp. nov. and Blastobotrys raffinosifermentans sp. nov., novel anamorphic yeast species
}

\author{
Cletus P. Kurtzman
}

Correspondence

Cletus P. Kurtzman

kurtzman@ncaur.usda.gov Microbial Genomics and Bioprocessing Research Unit, National Center for Agricultural
Utilization Research, Agricultural Research Service, US Department of Agriculture, $1815 \mathrm{~N}$.
University St, Peoria, IL 61604, USA
The dimorphic genus Blastobotrys was originally described as a hyphomycete (von Klopotek, 1967), but phylogenetic analysis of domains D1/D2 of the large-subunit (LSU) rDNA demonstrated that assigned species are actually anamorphic members of the Saccharomycetales (Kurtzman \& Robnett, 1995, 1998). The D1/D2 LSU rDNA analysis also showed close relatedness between Blastobotrys, Arxula, Sympodiomyces and several Candida species. More recently, Kurtzman \& Robnett (2007) re-examined relationships among these taxa with a more robust dataset consisting of nucleotide sequences from the nearly complete LSU rDNA, mitochondrial small-subunit (SSU) rDNA and the cytochrome oxidase II (COXII) gene. This multigene analysis demonstrated Blastobotrys, Arxula, Sympodiomyces and the above-noted Candida species to be members of the same clade, which was interpreted as a single genus. Of described genera, Blastobotrys (von Klopotek, 1967) has taxonomic priority for this clade over Arxula (van der Walt et al., 1990)

Abbreviations: LSU, large-subunit; SSU, small-subunit.

The GenBank/EMBL/DDBJ accession numbers for the LSU and mitochondrial SSU rDNA sequences, ITS sequences and COXII sequences of the proposed type strains and related strains are listed in Table 1. and Sympodiomyces (Fell \& Statzell, 1971), resulting in the transfer of species assigned to the latter two genera to Blastobotrys. The multigene sequence analysis also showed Trichomonascus to represent the ascosporic state of this clade. During the course of that study, six novel species of Blastobotrys were detected based on their unique nucleotide sequences in LSU rDNA, ITS rDNA, mitochondrial SSU rDNA and the COXII gene. In this report, descriptions are given for these six novel species.

Strains of the proposed novel species and reference taxa are given in Table 1 along with GenBank accession numbers for the genes sequenced. The strains are maintained in the Agricultural Research Service Culture Collection (NRRL), National Center for Agricultural Utilization Research, Peoria, IL, USA. Sources of the novel species are given in each species description. The composition of culture media used in this study, as well as the methods for fermentation and assimilation tests, was given previously (Yarrow, 1998).

Methods for DNA isolation and sequencing of domains D1/D2 of the LSU rDNA, as well as the nearly entire LSU rDNA, ITS1-5.8S-ITS2 rDNA, mitochondrial SSU rDNA and the COXII gene, were given by Kurtzman \& Robnett 
Table 1. GenBank accession numbers for the strains compared

Accession numbers are for the nearly complete LSU (26S) rDNA sequence (LSU), the ITS1-5.8S-ITS2 region (ITS), the mitochondrial SSU rDNA (MtSm) and the cytochrome oxidase II gene (COXII). T, Type strain; I, isotype strain.

\begin{tabular}{|c|c|c|c|c|}
\hline Strain & LSU & ITS & MtSm & COXII \\
\hline Blastobotrys illinoisensis sp. nov. NRRL YB- $1343^{\mathrm{T}}=\mathrm{CBS} 10339^{\mathrm{T}}$ & DQ442696 & DQ898169 & DQ442775 & DQ443103 \\
\hline Blastobotrys muscicola sp. nov. NRRL Y-7993 ${ }^{\mathrm{T}}=\mathrm{CBS} 10338^{\mathrm{T}}$ & DQ442680 & & DQ442759 & DQ443087 \\
\hline Blastobotrys peoriensis sp. nov. NRRL YB- $2290^{\mathrm{T}}=\mathrm{CBS} 10340^{\mathrm{T}}$ & DQ442700 & & DQ442779 & DQ443107 \\
\hline Blastobotrys arbuscula NRRL Y-17585 ${ }^{\mathrm{T}}=\mathrm{CBS} 227.83^{\mathrm{T}}$ & DQ442689 & & DQ442768 & DQ443096 \\
\hline Blastobotrys aristata NRRL Y $-17579^{\mathrm{T}}=\mathrm{CBS} 521.75^{\mathrm{T}}$ & DQ442686 & & DQ442765 & DQ443093 \\
\hline Blastobotrys capitulata NRRL Y $-17573^{\mathrm{T}}=\mathrm{CBS} 287.82^{\mathrm{T}}$ & DQ442688 & & DQ442767 & DQ443095 \\
\hline Blastobotrys chiropterorum NRRL Y-17071 ${ }^{\mathrm{T}}=\mathrm{CBS} 6064^{\mathrm{T}}$ & DQ442682 & & DQ442761 & DQ443089 \\
\hline Blastobotrys elegans NRRL Y-17572 ${ }^{\mathrm{T}}=\mathrm{CBS} 530.83^{\mathrm{T}}$ & DQ442687 & & DQ442766 & DQ443094 \\
\hline Blastobotrys proliferans NRRL Y-17577 ${ }^{\mathrm{T}}=\mathrm{CBS} 522.75^{\mathrm{T}}$ & DQ442684 & & DQ442763 & DQ443091 \\
\hline Blastobotrys terrestris NRRL Y-17704 ${ }^{\mathrm{T}}=\mathrm{CBS} 7376^{\mathrm{T}}$ & DQ442683 & & DQ442762 & DQ443090 \\
\hline Sporopachydermia lactativora NRRL Y-11591 ${ }^{\mathrm{T}}=\mathrm{CBS} 6192^{\mathrm{T}}$ & DQ438185 & & DQ442714 & DQ443042 \\
\hline Sugiyamaella smithiae NRRL Y-17850 ${ }^{\mathrm{I}}=\mathrm{CBS} 7522.2^{\mathrm{I}}$ & DQ438218 & & DQ442734 & DQ443062 \\
\hline Trichomonascus ciferrii NRRL Y-10943 ${ }^{\mathrm{I}}=\mathrm{CBS} 5295^{\mathrm{I}}$ & DQ442681 & & DQ442760 & DQ443088 \\
\hline Trichomonascus farinosus NRRL Y-17593 ${ }^{\mathrm{T}}=\mathrm{CBS} 140.71^{\mathrm{T}}$ & DQ442685 & & DQ442764 & DQ443092 \\
\hline Trichomonascus petasosporus NRRL YB- $2092^{\mathrm{T}}=\mathrm{CBS} 9602^{\mathrm{T}}$ & DQ442691 & & DQ442770 & DQ443098 \\
\hline Trigonopsis variabilis NRRL Y-1579 ${ }^{\mathrm{T}}=\mathrm{CBS} 1040^{\mathrm{T}}$ & DQ442707 & & DQ442785 & DQ443114 \\
\hline Wickerhamiella domercqiae NRRL Y-6692 ${ }^{\mathrm{T}}=\mathrm{CBS} 4351^{\mathrm{T}}$ & DQ438240 & & DQ442756 & DQ443084 \\
\hline Zygoascus hellenicus NRRL Y-7136 $6^{\mathrm{T}}=\mathrm{CBS} 5839^{\mathrm{T}}$ & DQ438216 & & DQ442719 & DQ443047 \\
\hline
\end{tabular}

${ }^{\star}$ The original spelling of the species epithet, indianaensis, has been treated as an orthographical error.

(1998, 2003, 2007). Both strands of the DNAs analysed were sequenced with the ABI BigDye Terminator Cycle Sequencing kit (Applied Biosystems) using either an ABI 3100 or an ABI 3730 automated DNA sequencer according to the manufacturer's instructions. For phylogenetic analysis, sequences were aligned visually and regions of uncertain alignment were removed. Estimates of phylogenetic relatedness among species were determined using the maximumparsimony and neighbour-joining programs of PAUP $^{*}$ 4.063a (Swofford, 1998). Bootstrap support for phylogenetic trees was determined from 1000 replications.

Maximum-parsimony analysis of concatenated nucleotide sequences from the nearly entire LSU rDNA, mitochondrial SSU rDNA and COXII gene demonstrated genetic separation of the six proposed novel species from previously described species in the Trichomonascus/Blastobotrys clade (Fig. 1). Results were the same when the dataset was analysed by neighbour-joining with Kimura's two-parameter correction. Two of the proposed novel species are closely related to each other and to Blastobotrys mokoenaii, and one of the proposed novel species is closely related to
Blastobotrys adeninivorans. Genetic separation of these species was further examined from ITS1-5.8S-ITS2 sequence analysis as discussed in the species descriptions. Sequences for LSU rDNA, mitochondrial SSU rDNA and the COXII gene were not determined for the recently described Sympodiomyces attinorum (Carreiro et al., 2004) in the present study but, because D1/D2 LSU rDNA sequence analysis showed it to be a sister species of Blastobotrys (Sympodiomyces) parvus, Kurtzman \& Robnett (2007) transferred it to Blastobotrys along with other species of Sympodiomyces.

Each of the proposed novel species is represented by just one strain. While it is desirable to base novel species descriptions on more than one isolate, type strains for most of the proposed novel species were obtained 30-50 years ago, and the probability of finding additional strains in the near future may be enhanced by these descriptions. Furthermore, awareness of these species brings additional perspective to the diversity within the genus Blastobotrys. The novel species Blastobotrys illinoisensis and Blastobotrys malaysiensis are closely related to each other and to $B$. mokoenaii on the basis of D1/D2 LSU divergence, and this is also seen for the species 


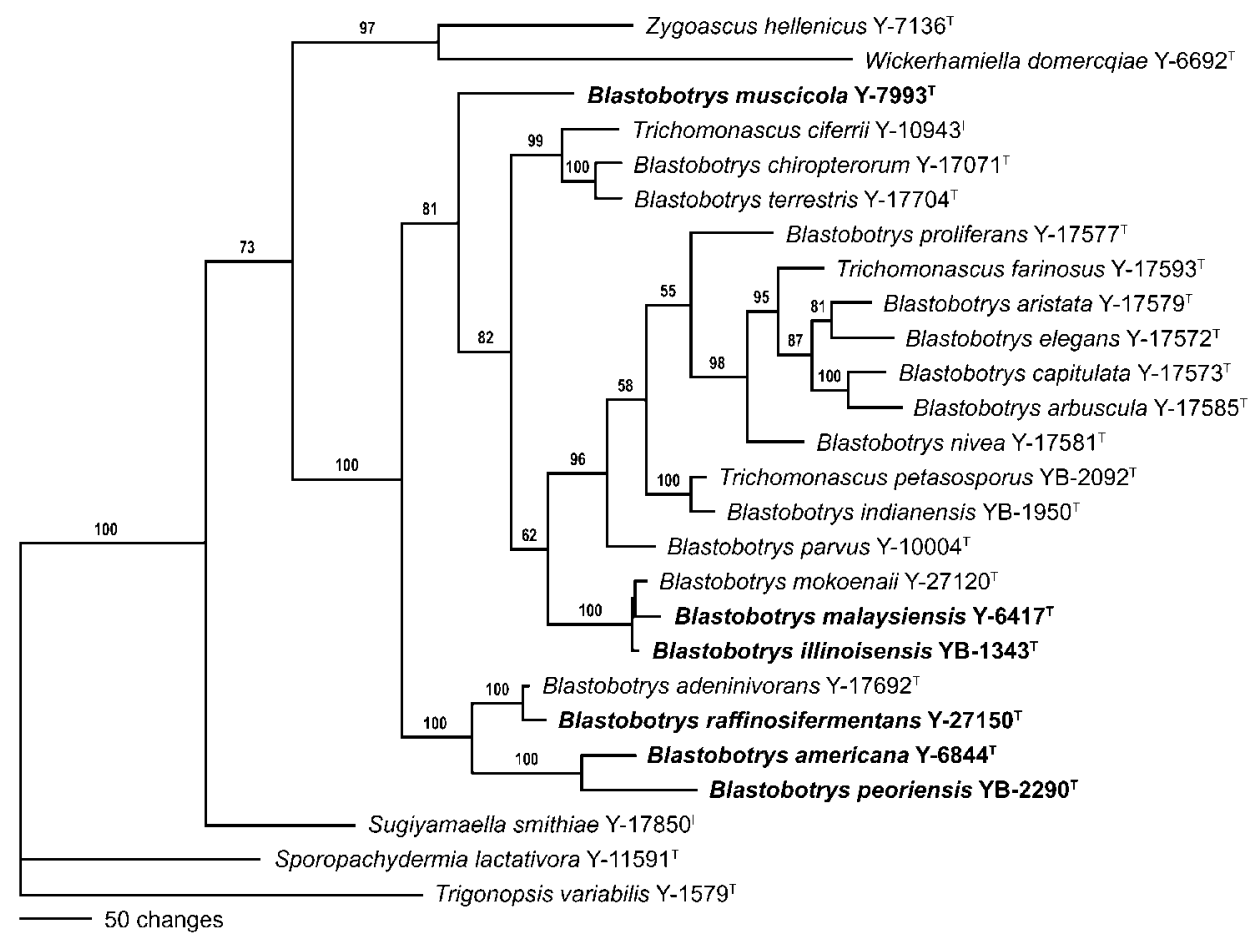

Fig. 1. Phylogenetic placement of the six proposed novel species of Blastobotrys among related ascomycetous yeasts as represented by the single most-parsimonious tree determined from maximum-parsimony analysis of nucleotide sequences from the nearly entire LSU rDNA, mitochondrial SSU rDNA and the COXII gene. Tree length $=2640$ steps, consistency index $=0.556$, retention index $=0.572$, rescaled consistency index $=0.318$, homoplasy index $=0.444$. Bootstrap values (1000 replicates) $\geqslant 50 \%$ are given at nodes. Trigonopsis variabilis NRRL Y-1579 ${ }^{\top}$ was the designated outgroup for the analysis. ARS Culture Collection strain numbers follow the names of taxa; GenBank accession numbers for the gene sequences are given in Table 1. Blastobotrys attinorum was not included in this multigene analysis, but D1/D2 LSU rDNA sequence analysis showed it to be a sister species of Blastobotrys parvus (Carreiro et al., 2004).

pair Blastobotrys raffinosifermentans and B. adeninivorans. Nucleotide divergence in ITS, mitochondrial SSU and the COXII gene is concordant with D1/D2 LSU divergence (Table 2) and further suggests that these taxa are separate species, because the divergence is greater than that seen between strains of a species in closely related clades (Kurtzman \& Robnett, 2007). Noteworthy in comparisons of these particular species pairs is that many of the sequence differences in ITS and mitochondrial SSU rDNA result from indels, whereas differences in D1/D2 LSU rDNA and the COXII gene are exclusively from nucleotide substitutions.

The genus Blastobotrys is unusual among yeasts because of the presence of setae, which are long, tapered, tail-like extensions of cell wall material arising from the ends of cells. In their treatment of Blastobotrys, de Hoog \& Smith (1998) reported that three of seven known species formed setae, i.e. Blastobotrys aristata, Blastobotrys capitulata and Blastobotrys

Table 2. Nucleotide divergence between closely related species of Blastobotrys

D1/D2, Domains 1 and 2 of LSU (26S) rDNA; ITS, ITS1-5.8S-ITS2 rDNA; MtSm, mitochondrial SSU rDNA; COXII, cytochrome oxidase II. s, Nucleotide substitution; i, indel.

\begin{tabular}{|c|c|c|c|c|}
\hline \multirow[t]{2}{*}{ Strain pair } & \multicolumn{4}{|c|}{ Nucleotide differences between strains } \\
\hline & D1/D2 & ITS & MtSm & COXII \\
\hline B. adeninivorans NRRL Y-17692 ${ }^{\mathrm{T}}-$ B. raffinosifermentans $\mathrm{NRRL} Y-27150^{\mathrm{T}}$ & $4 \mathrm{~s}$ & $3(2 s, 1 i)$ & $28(1 \mathrm{~s}, 27 \mathrm{i})$ & $17 \mathrm{~s}$ \\
\hline B. mokoenaii NRRL Y-27120 - B. malaysiensis NRRL Y- $6417^{\mathrm{T}}$ & $4 \mathrm{~s}$ & $6(4 s, 2 i)$ & $8(6 s, 2 i)$ & $19 \mathrm{~s}$ \\
\hline B. mokoenaii NRRL Y-27120 ${ }^{\mathrm{T}}-$ B. illinoisensis NRRL YB- $1343^{\mathrm{T}}$ & $2 \mathrm{~s}$ & $20(14 s, 6 i)$ & $2(1 \mathrm{~s}, 1 \mathrm{i})$ & $13 \mathrm{~s}$ \\
\hline B. malaysiensis NRRL Y-6417 - B. illinoisensis NRRL YB- $1343^{\mathrm{T}}$ & $2 \mathrm{~s}$ & $16(10 s, 6 i)$ & $10(7 \mathrm{~s}, 3 \mathrm{i})$ & $20 \mathrm{~s}$ \\
\hline
\end{tabular}


proliferans. In the present study, two of the six novel species, $B$. illinoisensis and B. malaysiensis, were found to produce setae, as did the recently described B. mokoenaii (Mokwena et al., 2000). Seta-forming species are not distributed uniformly within Blastobotrys and occur in only two subclades, but not all members of the $B$. proliferans subclade produce setae. All presently known ascosporogenous species of the Trichomonascus/Blastobotrys clade are heterothallic (Kurtzman, 2004; Smith \& de Hoog, 1998), which raises the possibility that anamorphic species in the clade may represent mating types.

\section{Latin diagnosis of Blastobotrys americana Kurtzman sp. nov.}

In agaro malti post dies 3 ad $25^{\circ} \mathrm{C}$, cellulae vegetativae globosae $(2.3-4.1 \mu \mathrm{m})$ aut elongatae $(1.3-3.5 \times 2.0-12.0 \mu \mathrm{m})$, singulae, binae et in racemis brevibus. In agaro morphologico post dies 7 ad $25^{\circ} \mathrm{C}$, incrementum fuscum pallidum, hebes, filamentosum; margo glabra vel undulata. Pseudohyphae et hyphae verae fiunt. Ascosporae non fiunt. Glucosum et trehalosum (infirme) fermentantur. Sucrosum, raffinosum, galactosum, lactosum et maltosum non fermentantur. Assimilantur glucosum, raffinosum, melibiosum, galactosum, trehalosum, methyl- $\alpha$-D-glucosidum, cellobiosum, salicinum, L-sorbosum, D-xylosum, L-arabinosum, D-arabinosum, Dribosum, ethanolum, glycerolum, erythritolum, ribitolum, galactitolum, D-mannitolum, D-glucitolum, inositolum, DL-acidum lacticum (infirme), acidum succinicum, D-gluconatum, D-glucosaminum, $N$-acetyl-D-glucosaminum, hexadecanum, 5-keto-D-gluconatum et cadaverinum. Non assimilantur inulinum, sucrosum, lactosum, maltosum, melezitosum, amylum solubile, L-rhamnosum, methanolum, acidum citricum, potassii nitras, 2-keto-D-gluconatum et saccharatum. Amylum non formatur. Vitamina externa ad crescentiam necessaria sunt. Gelatinum non liquescit; esteres non fiunt, pellicula fiunt. Crescit in medio $100 \mu \mathrm{g}$ cycloheximido $\mathrm{ml}^{-1}$ addito, et in medio $10 \%$ sodii chloridium $/ 5 \%$ glucosum. Augmentum non fiunt in temperatura $37^{\circ} \mathrm{C}$. Species nova a speciebus aliis sequentibus nucleotiditis nucleus submonas largus rRNA gene, mitochondrial submonas parvus rRNA gene et COXII gene distinguenda. Typus: NRRL Y$6844^{\mathrm{T}}\left(\mathrm{CBS} 10337^{\mathrm{T}}\right)$ designat stirpem typicam. Isolata $e$ substrato incognito, Kansas, USA. Depositata in Collectione Culturarum ARS (NRRL), Peoria, IL, USA.

\section{Description of Blastobotrys americana Kurtzman sp. nov.}

Blastobotrys americana (a.me.ri.ca' na. N.L. nom. fem. adj. americana from America, i.e. the USA).

After 3 days growth on $5 \%$ malt extract (ME) agar at $25^{\circ} \mathrm{C}$, budding is multilateral and cells are occasionally spherical, $2.3-4.1 \mu \mathrm{m}$, but are generally elongate, $1.3-3.5 \times 2.0$ $12.0 \mu \mathrm{m}$, single, in pairs and in short chains (Fig. 2a). Colony growth is restricted, dull, tannish-white in colour and mycelial. Growth under the cover glass of a Dalmau plate culture with yeast morphology (YMo) agar is quite restricted and is composed of pseudohyphae bearing infrequent blastoconidia after 7 days at $25^{\circ} \mathrm{C}$ (Fig. 2b). Aerobic growth on this medium is also restricted, dull, mycelial and tannish-white. The colony margin is entire to lobed. After 7-10 days, growth begins to show true hyphae, often with tip cells that are inflated and globose. However, these inflated hyphal cells do not appear to be asci. Occasionally, intercalary hyphal cells become enlarged and spherical. Cultures were examined weekly for ascospore formation on yeast extract, malt extract, peptone, glucose $(\mathrm{YM}), 5 \% \mathrm{ME}$, restricted growth (RG) and McClary's acetate agar media incubated at 15 and $25^{\circ} \mathrm{C}$. Ascospores were not detected after 3 months. Reactions for fermentation, assimilation and other diagnostic tests are given in Table 3. Dry, climbing pellicles are formed on stationary liquid media.

NRRL Y $-6844^{\mathrm{T}}\left(=\mathrm{CBS} 10337^{\mathrm{T}}\right)$ is the designated type strain and is preserved as a lyophilized preparation in the ARS Culture Collection (NRRL), Peoria, IL, USA. The strain was received by the ARS Culture Collection in 1965, as an unidentified isolate from Lekh Batra, then at the University of Kansas, Lawrence, KS, USA. The substrate from which the strain was isolated in Kansas was not described.

\section{Latin diagnosis of Blastobotrys illinoisensis Kurtzman sp. nov.}

In agaro malti post dies 3 ad $25^{\circ} \mathrm{C}$, cellulae vegetativae globosae $(2.0-4.0 \mu \mathrm{m})$ aut elongatae $(2.0-3.0 \times 2.5-8.0 \mu \mathrm{m})$ et ovoideae cellulae cum saetis $(1.0-1.3 \times 18-125 \mu \mathrm{m})$, singulae et binae. In agaro morphologico post dies 7 ad $25^{\circ} \mathrm{C}$, incrementum fuscum pallidum, hebes, filamentosum; margo glabra vel undulata. Pseudohyphae et hyphae verae fiunt. Ascosporae non fiunt. Glucosum, sucrosum (infirme), galactosum, trehalosum et maltosum fermentantur. Raffinosum et lactosum non fermentantur. Assimilantur glucosum, sucrosum, galactosum, maltosum, methyl- $\alpha$-D-glucosidum, amylum solubile, cellobiosum, salicinum, L-sorbosum, Lrhamnosum, D-xylosum, L-arabinosum, D-arabinosum, ethanolum, glycerolum, erythritolum, ribitolum, galactitolum, D-mannitolum, D-glucitolum, inositolum, acidum succinicum, acidum citricum, D-gluconatum, D-glucosaminum, $N$-acetyl-D-glucosaminum, hexadecanum, 2-keto-D-gluconatum, 5-keto-D-gluconatum et cadaverinum. Non assimilantur inulinum, raffinosum, melibiosum, lactosum, trehalosum, melezitosum, D-ribosum, methanolum, DL-acidum lacticum, potassii nitras et saccharatum. Amylum non formatur. Vitamina externa ad crescentiam necessaria non sunt. Gelatinum liquescit, esteres non fiunt; pellicula fiunt. Crescit in medio $100 \mu \mathrm{g}$ cycloheximido $\mathrm{ml}^{-1}$ addito, et in medio $10 \%$ sodii chloridium $/ 5 \%$ glucosum. Augmentum fiunt in temperatura $37^{\circ} \mathrm{C}$. Species nova a speciebus aliis sequentibus nucleotiditis nucleus submonas largus rRNA gene, ITS1-5.8SITS2 rRNA genes, mitochondrial submonas parvus rRNA gene et COXII gene distinguenda. Typus: NRRL YB- $1343^{\mathrm{T}}$ (CBS $10339^{\mathrm{T}}$ ) designat stirpem typicam. Isolata detrita a arbor mortua, Marion, IL, USA. Depositata in Collectione Culturarum ARS (NRRL), Peoria, IL, USA. 


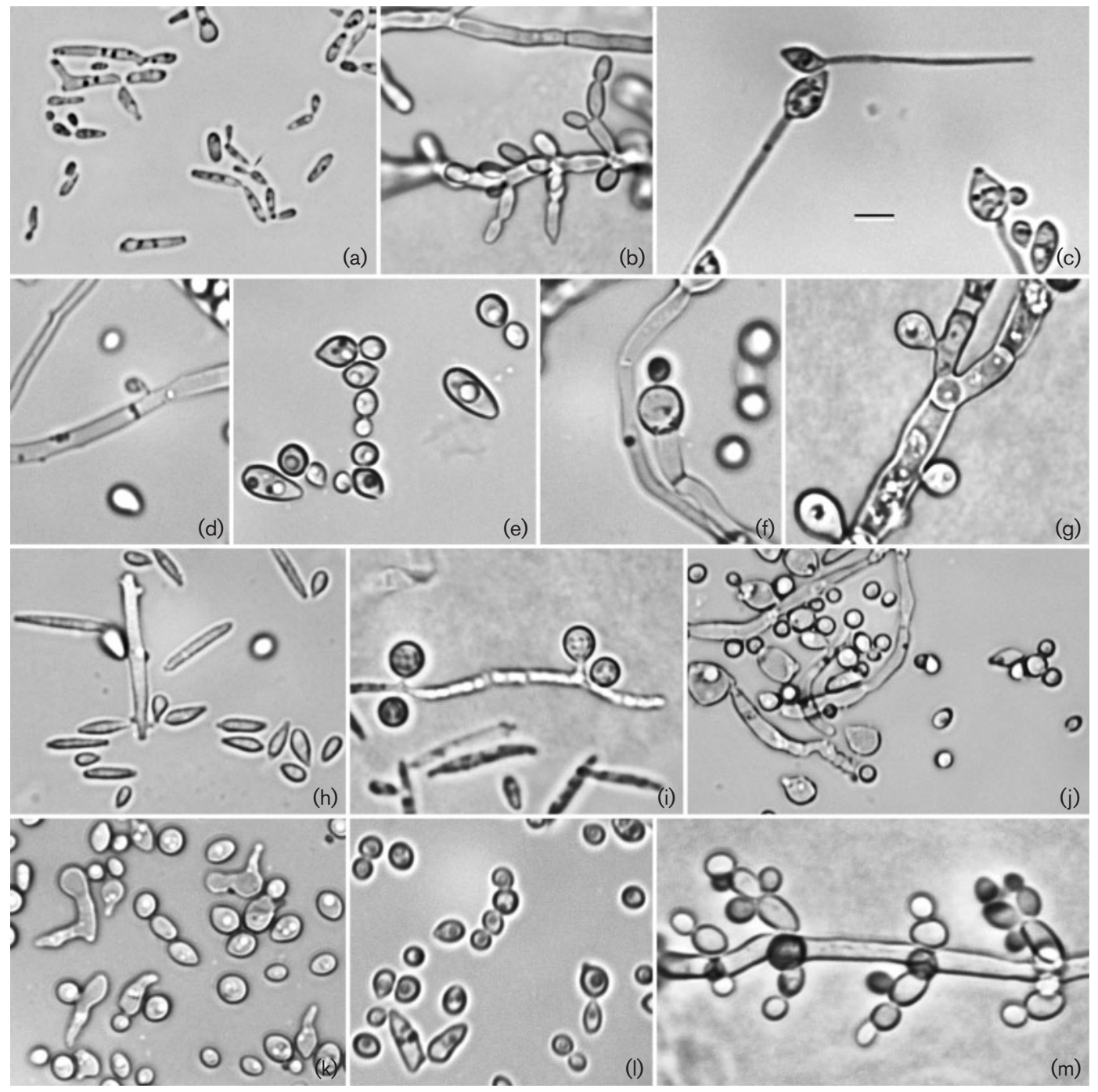

Fig. 2. Cellular morphology of the six novel species of Blastobotrys. (a-b) Blastobotrys americana NRRL Y-6844 ${ }^{\top}$ : budding cells (a); pseudohyphae (b). (c-d) Blastobotrys illinoisensis NRRL YB-1343 ${ }^{\mathrm{T}}$ : cells, some budded, with seta-like cell-wall extensions (c) (bar, $5 \mu \mathrm{m}$ ); denticulate hypha with a blastoconidium (d). (e-g) Blastobotrys malaysiensis NRRL Y-6417 ${ }^{\top}$ : budding cells (e); inflated hyphal tip cell with a bud (f); denticulate hypha with blastoconidia (g). (h-i) Blastobotrys muscicola NRRL $Y-7993^{\top}$ : spindle-shaped yeast cells and an elongated cell with terminal denticles ( $h$ ); large, spherical cells on a denticulate hypha (i). (j-k) Blastobotrys peoriensis NRRL YB-2290 ${ }^{\top}$ : budding cells and a pseudohyphal cell with a rachis-like tip (j); budding cells, some with tapered extensions that form blastoconidia (k). (I-m) Blastobotrys raffinosifermentans NRRL $\mathrm{Y}-27150^{\top}$ : budding cells $(\mathrm{I})$; pseudohypha with blastoconidia $(\mathrm{m})$. Cultures were grown on $5 \% \mathrm{ME}$ agar for 3 days at $25^{\circ} \mathrm{C}$ $(\mathrm{a}, \mathrm{c}, \mathrm{e}, \mathrm{f}, \mathrm{h}-\mathrm{j}, \mathrm{l})$ or on YMo agar for 7 days at $25^{\circ} \mathrm{C}(\mathrm{b}, \mathrm{d}, \mathrm{g}, \mathrm{k}, \mathrm{m})$. The bar in (c) applies to all panels.

\section{Description of Blastobotrys illinoisensis Kurtzman sp. nov.}

Blastobotrys illinoisensis (il.lin.ois.en'sis. N.L. nom. fem. adj. illinoisensis from the State of Illinois, USA).

After 3 days growth on $5 \% \mathrm{ME}$ agar at $25^{\circ} \mathrm{C}$, cells are spherical, $2.0-4.0 \mu \mathrm{m}$, to elongate, $2.0-3.0 \times 2.5-8.0 \mu \mathrm{m}$, and often teardrop-shaped. Cells form by multilateral budding and may be single or in pairs. Not infrequently, cells $4-5 \times 6-8 \mu \mathrm{m}$ have a tapered seta-like extension that has a basal diameter of $1.0-1.3 \mu \mathrm{m}$ and a length of $18-125 \mu \mathrm{m}$
(Fig. 2c). Seta-bearing cells often produce buds. Colony growth on $5 \% \mathrm{ME}$ agar is white with an almost powdery appearance and a prominent mycelial fringe. After 7 days at $25^{\circ} \mathrm{C}$, growth under the cover glass of a Dalmau plate culture with YMo agar shows pseudohyphae and abundant true hyphae with side branches having highly denticulate tips bearing blastoconidia. Hyphal cells also form denticles with blastoconidia (Fig. 2d). Aerobic colonies are white, mycelial and somewhat powdery with an entire to lobate margin. Reactions for fermentation, assimilation and other diagnostic tests are given in Table 3. Moderately thick, 
Table 3. Comparative physiological characteristics of the six novel Blastobotrys species

Strains: 1, B. americana NRRL Y-6844 $4^{\mathrm{T}}$; 2, B. illinoisensis NRRL YB-1343 ${ }^{\mathrm{T}}$; 3, B. malaysiensis NRRL $\mathrm{Y}-6417^{\mathrm{T}}$; 4, B. muscicola NRRL Y-7993 ${ }^{\mathrm{T}}$; 5, B. peoriensis NRRL YB-2290 ${ }^{\mathrm{T}}$; 6, B. raffinosifermentans NRRL Y-27150 ${ }^{\mathrm{T}}$. None of the strains fermented lactose. All assimilated glucose, galactose, cellobiose, glycerol, D-mannitol, succinate, $\mathrm{N}$-acetyl-D-glucosamine and cadaverine. Strains were not inhibited by cycloheximide at $100 \mu \mathrm{g} \mathrm{ml}^{-1}$. None of the strains assimilated methanol or saccharate and none formed extracellular starch-like compounds. -, Negative; +, positive; W, weak; V, strain variable (positive or negative). Variable reactions are based on a repeat using the same strain and resulted from a delayed positive reaction in some of the tests.

\begin{tabular}{|c|c|c|c|c|c|c|}
\hline Physiological test & 1 & 2 & 3 & 4 & 5 & 6 \\
\hline \multicolumn{7}{|l|}{ Fermentation of: } \\
\hline Glucose & + & + & + & - & + & + \\
\hline Sucrose & - & $\mathrm{W}$ & $\mathrm{W}$ & - & - & $\mathrm{w}$ \\
\hline Raffinose & - & - & - & - & - & + \\
\hline Galactose & - & + & + & - & + & + \\
\hline Trehalose & $\mathrm{W}$ & + & + & - & + & + \\
\hline Maltose & - & + & + & - & - & + \\
\hline \multicolumn{7}{|l|}{ Assimilation of: } \\
\hline Inulin & - & - & - & - & - & + \\
\hline Sucrose & - & + & + & + & + & + \\
\hline Raffinose & + & - & - & $\mathrm{V}$ & + & + \\
\hline Melibiose & + & - & - & $\mathrm{V}$ & + & + \\
\hline Lactose & - & - & + & + & + & - \\
\hline Trehalose & + & - & + & $\mathrm{V}$ & - & - \\
\hline Maltose & - & + & + & + & + & + \\
\hline Melezitose & - & - & $\mathrm{W}$ & + & + & + \\
\hline Methyl $\alpha$-D-glucoside & + & + & + & $\mathrm{V}$ & + & + \\
\hline Soluble starch & - & + & + & + & $\mathrm{w}$ & + \\
\hline Salicin & + & + & + & $\mathrm{V}$ & + & + \\
\hline L-Sorbose & + & + & + & - & + & + \\
\hline L-Rhamnose & - & + & + & - & - & - \\
\hline D-Xylose & + & + & + & - & + & + \\
\hline L-Arabinose & + & + & + & - & + & + \\
\hline D-Arabinose & + & + & + & - & + & + \\
\hline D-Ribose & + & - & + & - & + & + \\
\hline Ethanol & + & + & + & - & + & + \\
\hline Erythritol & + & + & + & - & + & + \\
\hline Ribitol & + & + & + & - & + & + \\
\hline Galactitol & + & + & - & - & + & + \\
\hline D-Glucitol & + & + & + & - & + & + \\
\hline Inositol & + & + & + & - & + & + \\
\hline DL-Lactate & $\mathrm{W}$ & - & + & - & - & + \\
\hline Citrate & - & + & + & + & - & + \\
\hline D-Gluconate & + & + & - & - & + & + \\
\hline D-Glucosamine & + & + & + & $\mathrm{V}$ & + & + \\
\hline Hexadecane & + & + & - & - & + & + \\
\hline Nitrate & - & - & - & - & + & + \\
\hline 2-Keto-D-gluconate & - & + & + & - & + & + \\
\hline 5-Keto-D-gluconate & + & + & + & - & + & + \\
\hline \multicolumn{7}{|l|}{ Additional growth tests } \\
\hline Growth in vitamin-free medium & - & + & + & $\mathrm{V}$ & - & - \\
\hline Growth in $10 \% \mathrm{NaCl} / 5 \%$ glucose & + & + & + & - & + & + \\
\hline Gelatin liquefaction & - & + & + & + & - & - \\
\hline Growth at $37^{\circ} \mathrm{C}$ & - & + & + & + & - & + \\
\hline
\end{tabular}


climbing pellicles are formed on stationary liquid media. Cultures grown on YM, $5 \% \mathrm{ME}$ and RG agar media at 15 and $25^{\circ} \mathrm{C}$ produced no ascospores after 6 weeks. The type strain differs from B. mokoenaii NRRL Y $-27120^{\mathrm{T}}$ and $B$. malaysiensis sp. nov. NRRL Y-6417 ${ }^{\mathrm{T}}$ by just two nucleotide substitutions in the D1/D2 domain of the LSU rDNA. This small difference raised the possibility that the taxa may be conspecific. However, greater divergence was found in the nucleotide sequences of ITS1-5.8S-ITS2 rDNA, mitochondrial SSU rDNA and the COXII gene, providing additional evidence that the three taxa are closely related but separate species (Table 2). In further tests, cultures of the three species were mixed on YM, $5 \%$ ME and RG media, incubated at $25^{\circ} \mathrm{C}$ and observed over a 6-week period. Neither conjugation between cells nor ascospores was detected. Cultures of B. mokoenaii, especially on $5 \%$ ME agar, occasionally formed spherical endospores in hyphal cells.

NRRL YB- $1343^{\mathrm{T}}\left(=\mathrm{CBS} 10339^{\mathrm{T}}\right)$ is the designated type strain and is preserved as a lyophilized preparation in the ARS Culture Collection (NRRL), Peoria, IL, USA. The strain was isolated by L. J. Wickerham in 1949, from debris surrounding the base of a standing, dead deciduous tree near Marion, IL, USA.

\section{Latin diagnosis of Blastobotrys malaysiensis Kurtzman sp. nov.}

In agaro malti post dies 3 ad $25^{\circ} \mathrm{C}$, cellulae vegetativae globosae $(3.0-5.5 \mu \mathrm{m})$ aut ellipsoideae $(2.5-4.0 \times 3.5-$ $6.0 \mu \mathrm{m})$ et ovoideae cellulae cum saetis, singulae et binae. In agaro morphologico post dies 7 ad $25^{\circ} \mathrm{C}$, incrementum fuscum pallidum, hebes et filamentosum; margo glabra vel undulata. Pseudohyphae et hyphae verae fiunt. Ascosporae non fiunt. Glucosum, sucrosum (infirme), galactosum, trehalosum et maltosum fermentantur. Raffinosum et lactosum non fermentantur. Assimilantur glucosum, sucrosum, galactosum, lactosum, trehalosum, maltosum, melezitosum (infirme), methyl- $\alpha$-D-glucosidum, amylum solubile, cellobiosum, salicinum, L-sorbosum, L-rhamnosum, D-xylosum, L-arabinosum, D-arabinosum, D-ribosum, ethanolum, glycerolum, erythritolum, ribitolum, D-mannitolum, D-glucitolum, inositolum, DL-acidum lacticum, acidum succinicum, acidum citricum, D-glucosaminum, N-acetyl-D-glucosaminum, 2keto-D-gluconatum, 5-keto-D-gluconatum et cadaverinum. Non assimilantur inulinum, raffinosum, melibiosum, methanolum, galactitolum, D-gluconatum, hexadecanum, potassii nitras et saccharatum. Amylum non formatur. Vitamina externa ad crescentiam necessaria non sunt. Gelatinum liquescit, esteres non fiunt, pellicula fiunt. Crescit in medio $100 \mu \mathrm{g}$ cycloheximido $\mathrm{ml}^{-1}$ addito, et in medio $10 \%$ sodii chloridium $/ 5 \%$ glucosum. Augmentum fiunt in temperatura $37^{\circ} \mathrm{C}$. Species nova a speciebus aliis sequentibus nucleotiditis nucleus submonas largus rRNA gene, ITS1-5.8S-ITS2 rDNA genes, mitochondrial submonas parvus rRNA gene et COXII gene distinguenda. Typus: NRRL Y-6417 ${ }^{\mathrm{T}}$ (CBS 10336 ${ }^{\mathrm{T}}$ ) designat stirpem typicam. Isolata soli, Malaysia. Depositata in Collectione Culturarum ARS (NRRL), Peoria, IL, USA.

\section{Description of Blastobotrys malaysiensis Kurtzman sp. nov.}

Blastobotrys malaysiensis (ma.lay.si.en'sis. N.L. nom. fem. adj. malaysiensis from the country of Malaysia).

After 3 days growth on $5 \% \mathrm{ME}$ agar at $25^{\circ} \mathrm{C}$, yeast cells are spherical, 3.0-5.5 $\mu \mathrm{m}$, to ellipsoidal, $2.5-4.0 \times 3.5-6.0 \mu \mathrm{m}$, form by multilateral budding and occur singly or in pairs (Fig. 2e). In addition, seta-bearing cells are also present, as seen for B. illinoisensis and B. mokoenaii (observation from this study), but lengths of setae seldom exceed $25 \mu \mathrm{m}$. Growth on $5 \%$ ME agar is tannish-white, dull, somewhat butyrous and with a prominent mycelial fringe. Growth under the cover glass of a Dalmau plate culture with YMo agar shows mostly true hyphae with a few interspersed pseudohyphae after 7 days at $25^{\circ} \mathrm{C}$. Aerobic growth is white, mycelial and almost powdery, with radial furrows and with margins that are broadly lobate. Hyphae on various media often show a spherical, inflated terminal cell that may produce buds (Fig. 2f). Blastoconidia often form on short denticles on the hyphal cells (Fig. 2g). Cultures grown on YM, $5 \% \mathrm{ME}$ and RG agar media incubated at 15 and $25^{\circ} \mathrm{C}$ produced no ascospores after 6 weeks and, as noted above, there was no mating reaction or ascosporulation in mixtures with the closely related species B. illinoisensis and B. mokoenaii. Reactions for fermentation, assimilation and other diagnostic tests are given in Table 3. Dry, climbing pellicles are formed on stationary liquid media.

NRRL Y $-6417^{\mathrm{T}}\left(=\mathrm{CBS} 10336^{\mathrm{T}}\right)$ is the designated type strain and is preserved as a lyophilized preparation in the ARS Culture Collection (NRRL), Peoria, IL, USA. The strain was received by the ARS Culture Collection in 1963 from Chester $\mathrm{W}$. Emmons, who reported that the strain had been isolated from soil in a cave in Malaysia.

\section{Latin diagnosis of Blastobotrys muscicola Kurtzman sp. nov.}

In agaro malti post dies 3 ad $25^{\circ} \mathrm{C}$, cellulae vegetativae globosae $(2.0-4.1 \mu \mathrm{m})$ aut elongatae et fusiformae (1.5-2.5 $\times$ $8.0-22.0 \mu \mathrm{m})$, singulae et binae. In agaro morphologico post dies 7 ad $25^{\circ} \mathrm{C}$, incrementum fuscum pallidum, hebes, filamentosum; margo undulata. Pseudohyphae et hyphae verae fiunt. Ascosporae non fiunt. Saccharas non fermentantur. Assimilantur glucosum, sucrosum, raffinosum (variabile), melibiosum (variabile), galactosum, lactosum, trehalosum (variabile), maltosum, melezitosum, methyl- $\alpha$-D-glucosidum (variabile), amylum solubile, cellobiosum, salicinum (variabile), glycerolum, D-mannitolum, acidum succinicum, acidum citricum, D-glucosaminum (variabile), N-acetyl-D-glucosaminum et cadaverinum. Non assimilantur inulinum, Lsorbosum, L-rhamnosum, D-xylosum, L-arabinosum, D-arabinosum, D-ribosum, methanolum, ethanolum, erythritolum, ribitolum, galactitolum, D-glucitolum, inositolum, DL-acidum lacticum, D-gluconatum, hexadecanum, potassii nitras, 2keto-D-gluconatum, 5-keto-D-gluconatum et saccharatum. Amylum non formatur. Vitamina externa ad crescentiam 
necessaria non sunt (variabile). Gelatinum liquescit, esteres non fiunt, pellicula fiunt. Crescit in medio $100 \mu \mathrm{g}$ cycloheximido $\mathrm{ml}^{-1}$ addito. Non crescit in medio $10 \%$ sodii chloridium $/ 5 \%$ glucosum. Augmentum fiunt in temperatura $37^{\circ} \mathrm{C}$. Species nova a speciebus aliis sequentibus nucleotiditis nucleus submonas largus rRNA gene, mitochondrial submonas parvus rRNA gene et COXII gene distinguenda. Typus: NRRL Y$7993^{\mathrm{T}}\left(\mathrm{CBS} 10338^{\mathrm{T}}\right)$ designat stirpem typicam. Isolata musca, propinqua New Orleans, LA, USA. Depositata in Collectione Culturarum ARS (NRRL), Peoria, IL, USA.

\section{Description of Blastobotrys muscicola Kurtzman sp. nov.}

Blastobotrys muscicola (mus.ci'co.la. N.L. nom. fem. n. muscicola moss-dweller).

After 3 days growth on $5 \% \mathrm{ME}$ agar at $25^{\circ} \mathrm{C}$, budding is multilateral and cells are single or in pairs, infrequently spherical, $2.0-4.1 \mu \mathrm{m}$, but the majority are elongate and often spindle-shaped, $1.5-2.5 \times 8.0-22.0 \mu \mathrm{m} \quad$ (Fig. $2 \mathrm{~h}$ ). Larger elongated cells often form terminal denticles that produce blastoconidia. Colony growth is dull, white and mycelial. Growth under the cover glass of a Dalmau plate culture with YMo agar shows both true hyphae and pseudohyphae after 7 days at $25^{\circ} \mathrm{C}$. Aerobic growth on this medium is dull, white and mycelial with a lobate margin. Cultures were examined weekly for ascospore formation on YM, $5 \%$ ME, RG and McClary's acetate agar media incubated at 15 and $25^{\circ} \mathrm{C}$, but ascospores were not detected after 3 months. Hyphae on various media develop inflated spherical cells borne on short denticles (Fig. 2i), but these cells do not form ascospores and do not appear to be asci. Reactions for fermentation, assimilation and other diagnostic tests are given in Table 3. Dry, climbing pellicles are formed on stationary liquid media.

NRRL Y $-7993^{\mathrm{T}}\left(=\mathrm{CBS} 10338^{\mathrm{T}}\right)$ is the designated type strain and is preserved as a lyophilized preparation in the ARS Culture Collection (NRRL), Peoria, IL, USA. The strain was isolated by the author in 1976 from an unidentified moss growing on a fallen log in a wilderness area in St Tammany Parish, near New Orleans, LA, USA.

\section{Latin diagnosis of Blastobotrys peoriensis Kurtzman sp. nov.}

In agaro malti post dies 3 ad $25^{\circ} \mathrm{C}$, cellulae vegetativae globosae $(2.0-5.0 \mu \mathrm{m})$ aut elongatae $(2.0-4.0 \times 2.5-12.0 \mu \mathrm{m})$, singulae et binae. In agaro morphologico post dies 7 ad $25^{\circ} \mathrm{C}$, incrementum fuscum pallidum, hebes, butyrosum; margo glabra vel serrata. Pseudohyphae et hyphae verae fiunt. Ascosporae non fiunt. Glucosum, galactosum et trehalosum fermentantur. Sucrosum, raffinosum, lactosum et maltosum non fermentantur. Assimilantur glucosum, sucrosum, raffinosum, melibiosum, galactosum, lactosum, maltosum, melezitosum, methyl- $\alpha$-D-glucosidum, amylum solubile (infirme), cellobiosum, salicinum, L-sorbosum, D-xylosum, L-arabinosum, D-arabinosum, D-ribosum, ethanolum, glycerolum, erythritolum, ribitolum, galactitolum, D-mannitolum, Dglucitolum, inositolum, acidum succinicum, D-gluconatum, D-glucosaminum, N-acetyl-D-glucosaminum, hexadecanum, potassii nitras, 2-keto-D-gluconatum, 5-keto-D-gluconatum et cadaverinum. Non assimilantur inulinum, trehalosum, L-rhamnosum, methanolum, DL-acidum lacticum, acidum citricum et saccharatum. Amylum non formatur. Vitamina externa ad crescentiam necessaria sunt. Gelatinum non liquescit, esteres non fiunt; pellicula fiunt. Crescit in medio $100 \mu \mathrm{g}$ cycloheximido $\mathrm{ml}^{-1}$ addito, et in medio $10 \%$ sodii chloridium $/ 5 \%$ glucosum. Augmentum non fiunt in temperatura $37^{\circ} \mathrm{C}$. Species nova a speciebus aliis sequentibus nucleotiditis nucleus submonas largus rRNA gene, mitochondrial submonas parvus rRNA gene et COXII gene distinguenda. Typus: NRRL YB-2290 ${ }^{\mathrm{T}}$ (CBS 10340 ${ }^{\mathrm{T}}$ ) designat stirpem typicam. Isolatus ex fungus incognitus, Peoria, IL, USA. Depositata in Collectione Culturarum ARS (NRRL), Peoria, IL, USA.

\section{Description of Blastobotrys peoriensis Kurtzman sp. nov.}

Blastobotrys peoriensis (pe.o.ri.en'sis. N.L. nom. fem. adj. peoriensis from Peoria, IL, USA, the collection site of the type strain).

After 3 days growth on $5 \% \mathrm{ME}$ agar at $25^{\circ} \mathrm{C}$, cells are spherical, $2.0-5.0 \mu \mathrm{m}$, ovoid and elongate, $2.0-4.0 \times 2.5-$ $12.0 \mu \mathrm{m}$, occur singly or in pairs and divide by multilateral budding (Fig. 2j, k). Colony growth is tannish-white and dull and ranges from butyrous to mycelial. Growth under the cover glass of a Dalmau plate culture with YMo agar shows abundant pseudohyphae with clusters of blastoconidia after 7 days at $25^{\circ} \mathrm{C}$. True hyphae are infrequent but become more common in older cultures. Both hyphae and individual cells form rachis-like extensions that produce blastoconidia (Fig. 2j, k). Aerobic colony growth on the Dalmau plate is white to tannish-white, dull with a convoluted surface and butyrous in texture. Ascosporulation was not observed in cultures grown on YM, $5 \% \mathrm{ME}$, RG and McClary's acetate agar media incubated at 15 and $25^{\circ} \mathrm{C}$ for 3 months. Reactions for fermentation, assimilation and other diagnostic tests are given in Table 3. Thick pellicles are formed on stationary liquid media.

NRRL YB- $2290^{\mathrm{T}}\left(=\mathrm{CBS} 10340^{\mathrm{T}}\right)$ is the designated type strain and is preserved as a lyophilized preparation in the ARS Culture Collection (NRRL), Peoria, IL, USA. The strain was isolated in 1950 by L. J. Wickerham from unidentified fungal growth on a rotted log, Peoria, IL, USA.

\section{Latin diagnosis of Blastobotrys raffinosifermentans Kurtzman sp. nov.}

In agaro malti post dies 3 ad $25^{\circ} \mathrm{C}$, cellulae vegetativae globosae $(2.0-4.0 \mu \mathrm{m})$ aut elongatae $(2.0-3.5 \times 3.0-13.0 \mu \mathrm{m})$, singulae, binae et fasciculatae. In agaro morphologico post dies 7 ad $25^{\circ} \mathrm{C}$, incrementum fuscum pallidum, hebes et butyrosum; margo glabra vel undulata. Pseudohyphae fiunt, hyphae 
verae non fiunt. Ascosporae non fiunt. Glucosum, sucrosum (infirme), raffinosum, galactosum, trehalosum et maltosum fermentantur. Lactosum non fermentatur. Assimilantur glucosum, inulinum, sucrosum, raffinosum, melibiosum, galactosum, maltosum, melezitosum, methyl- $\alpha$-D-glucosidum, amylum solubile, cellobiosum, salicinum, L-sorbosum, D-xylosum, L-arabinosum, D-arabinosum, D-ribosum, ethanolum, glycerolum, erythritolum, ribitolum, galactitolum, D-mannitolum, D-glucitolum, inositolum, DL-acidum lacticum, acidum succinicum, acidum citricum, D-gluconatum, D-glucosaminum, N-acetyl-D-glucosaminum, hexadecanum, potassii nitras, 2-keto-D-gluconatum, 5-keto-D-gluconatum et cadaverinum. Non assimilantur lactosum, trehalosum, L-rhamnosum, methanolum et saccharatum. Amylum non formatur. Vitamina externa ad crescentiam necessaria sunt. Gelatinum non liquescit, esteres non fiunt, pellicula funt. Crescit in medio $100 \mu \mathrm{g}$ cycloheximido $\mathrm{ml}^{-1}$ addito, et in medio $10 \%$ sodii chloridium $/ 5 \%$ glucosum. Augmentum fiunt in temperatura $37^{\circ} \mathrm{C}$. Species nova a speciebus aliis sequentibus nucleotiditis nucleus submonas largus rRNA gene, mitochondrial submonas parvus rRNA gene et COXII gene distinguenda. Typus: NRRL $\mathrm{Y}-27150^{\mathrm{T}}\left(\mathrm{CBS} 6800^{\mathrm{T}}\right)$ designat stirpem typicam. Isolata e substrato incognito. Depositata in Collectione Culturarum ARS (NRRL), Peoria, IL, USA.

\section{Description of Blastobotrys raffinosifermentans Kurtzman sp. nov.}

Blastobotrys raffinosifermentans (raf'fi.no.si.fer.men'tans. N.L. part. adj. raffinosifermentans fermenting raffinose, a property rare among species of the Trichomonascusl Blastobotrys clade).

After 3 days growth on $5 \% \mathrm{ME}$ agar at $25^{\circ} \mathrm{C}$, cells are spherical, $2.0-4.0 \mu \mathrm{m}$, to elongate, $2.0-3.5 \times 3.0-13.0 \mu \mathrm{m}$, and occur singly, in pairs and in small clusters (Fig. 2l). Budding is multilateral. Some cells form short denticles that produce blastoconidia. Colony growth is white, dull and butyrous. Growth under the cover glass of a Dalmau plate culture with YMo agar shows abundant well-branched pseudohyphae bearing blastoconidia after 7 days at $25^{\circ} \mathrm{C}$ (Fig. $2 \mathrm{~m}$ ), but true hyphae are not detected. Aerobic colony growth is tannish-white, smooth, dull, with a cupulate centre and margins with infrequent small lobes. Ascosporulation was not observed in cultures grown on YM, $5 \% \mathrm{ME}$ and RG agar media at 15 and $25{ }^{\circ} \mathrm{C}$ for 2 months. Reactions for fermentation, assimilation and other diagnostic tests are given in Table 3. Moderately thick, climbing pellicles form on stationary liquid media.

NRRL Y $-27150^{\mathrm{T}}\left(=\mathrm{CBS} 6800^{\mathrm{T}}\right)$ is the designated type strain and is preserved as a lyophilized preparation in the ARS Culture Collection (NRRL), Peoria, IL, USA. The strain was received at the CBS Culture Collection from J. Shennan, but the source is unknown.

\section{Acknowledgements}

Christie J. Robnett is gratefully acknowledged for determining DNA sequences for the novel species, Eleanor Basehoar-Powers for conducting fermentation and assimilation tests and Don Fraser for preparing final figures. The mention of firm names or trade products does not imply that they are endorsed or recommended by the US Department of Agriculture over other firms or similar products not mentioned.

\section{References}

Carreiro, S. C., Pagnocca, F. C., Bacci, M., Jr, Lachance, M.-A., Bueno, O. C., Hebling, M. J. A., Ruivo, C. C. C. \& Rosa, C. A. (2004). Sympodiomyces attinorum sp. nov., a yeast species associated with nests of the leaf-cutting ant Atta sexdens. Int J Syst Evol Microbiol 54, 1891-1894.

de Hoog, G. S. \& Smith, M. Th. (1998). Blastobotrys von Klopotek. In The Yeasts, a Taxonomic Study, 4th edn, pp. 443-448. Edited by C. P. Kurtzman \& J. W. Fell. Amsterdam: Elsevier.

Fell, J. W. \& Statzell, A. C. (1971). Sympodiomyces gen. n., a yeast-like organism from southern marine waters. Antonie van Leeuwenhoek 37, 359-367.

Kurtzman, C. P. (2004). Trichomonas petasosporus sp. nov. and Sympodiomyces indianaensis sp. nov., two new members of the Saccharomycetales. Antonie van Leeuwenhoek 85, 297-304.

Kurtzman, C. P. \& Robnett, C. J. (1995). Molecular relationships among hyphal ascomycetous yeasts and yeastlike taxa. Can J Bot 73, S824-S830.

Kurtzman, C. P. \& Robnett, C. J. (1998). Identification and phylogeny of ascomycetous yeasts from analysis of nuclear large subunit (26S) ribosomal DNA partial sequences. Antonie van Leeuwenhoek 73, 331-371.

Kurtzman, C. P. \& Robnett, C. J. (2003). Phylogenetic relationships among yeasts of the 'Saccharomyces complex' determined from multigene sequence analyses. FEMS Yeast Res 3, 417-432.

Kurtzman, C. P. \& Robnett, C. J. (2007). Multigene phylogenetic analysis of the Trichomonascus, Wickerhamiella and Zygoascus yeast clades, and the proposal of Sugiyamaella gen. nov. and 14 new species combinations. FEMS Yeast Res 7, 141-151.

Mokwena, T. A., van Rensburg, E. \& Myburgh, J. (2000). The isolation and classification of Candida mokoenaii sp. nov., a new yeast isolate from South African soil. Antonie van Leeuwenhoek 77, 43-47.

Smith, M. Th. \& de Hoog, G. S. (1998). Stephanoascus M. Th. Smith, van der Walt \& E. Johannsen. In The Yeasts, a Taxonomic Study, 4th edn, pp. 400-403. Edited by C. P. Kurtzman \& J. W. Fell. Amsterdam: Elsevier.

Swofford, D. L. (1998). PAUP* 4.0 - phylogenetic analysis using parsimony. Sunderland, MA: Sinauer.

van der Walt, J. P., Smith, M. Th. \& Yamada, Y. (1990). Arxula gen. nov. (Candidaceae), a new anamorphic, arthroconidial yeast genus. Antonie van Leeuwenhoek 57, 59-61.

von Klopotek, A. (1967). Blastobotrys nivea gen. nov., sp. nov. Arch Mikrobiol 58, 92-96.

Yarrow, D. (1998). Methods for the isolation, maintenance and identification of yeasts. In The Yeasts, a Taxonomic Study, 4th edn, pp. 77-100. Edited by C. P. Kurtzman \& J. W. Fell. Amsterdam: Elsevier. 